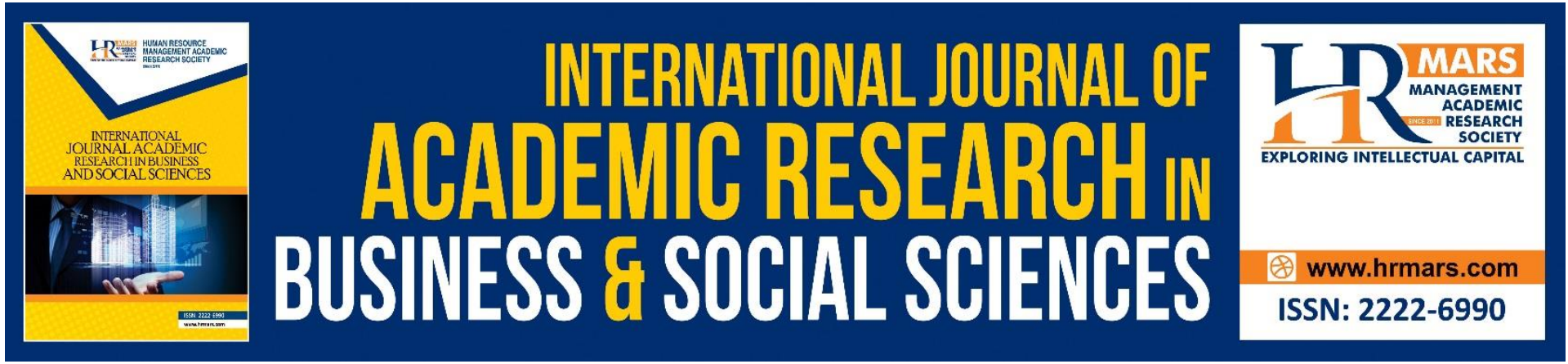

\title{
A Conceptual Framework for Customer Experience Towards COVID-19 Preventive Measures of Malaysian Retailers
}

Fatin Husna Suib, Suharni Maulan, Amirah Ahmad Suki

To Link this Article: http://dx.doi.org/10.6007/IJARBSS/v11-i6/10338

DOI:10.6007/IJARBSS/v11-i6/10338

Received: 24 April 2021, Revised: 26 May 2021, Accepted: 10 June 2021

Published Online: 28 June 2021

In-Text Citation: (Suib et al., 2021)

To Cite this Article: Suib, F. H., Maulan, S., \& Suki, A. A. (2021). A Conceptual Framework for Customer Experience Towards COVID-19 Preventive Measures of Malaysian Retailers. International Journal of Academic Research in Business and Social Sciences, 11(6), 1279-1292.

Copyright: @ 2021 The Author(s)

Published by Human Resource Management Academic Research Society (www.hrmars.com)

This article is published under the Creative Commons Attribution (CC BY 4.0) license. Anyone may reproduce, distribute, translate and create derivative works of this article (for both commercial and non-commercial purposes), subject to full attribution to the original publication and authors. The full terms of this license may be seen

at: http://creativecommons.org/licences/by/4.0/legalcode

Vol. 11, No. 6, 2021, Pg. 1279 - 1292

http://hrmars.com/index.php/pages/detail/IJARBSS

JOURNAL HOMEPAGE

Full Terms \& Conditions of access and use can be found at http://hrmars.com/index.php/pages/detail/publication-ethics 


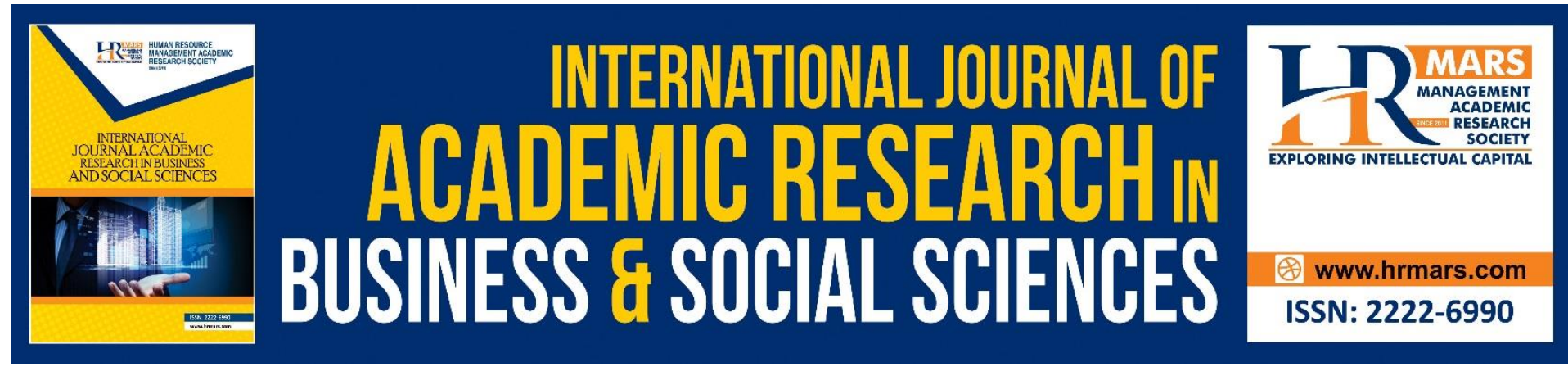

\title{
A Conceptual Framework for Customer Experience Towards COVID-19 Preventive Measures of Malaysian Retailers
}

\author{
Fatin Husna Suib, Suharni Maulan, Amirah Ahmad Suki \\ Department of Business Administration, Kulliyyah of Economics and Management Sciences, \\ International Islamic University Malaysia, 53100 Gombak, Selangor, Malaysia. \\ Email: fatinhusnasuib@iium.edu.my, suharni@iium.edu.my,mirahahmadsuki@iium.edu.my
}

\begin{abstract}
This study develops a framework on customer experience towards COVID-19 preventive measures of Malaysian retailers. Specifically, it proposes a conceptual framework of In-Store Customer Experience (ISCX) and preventive measures within the implementation of the Maslow Hierarchy of Needs concept. Eventually, the upcoming focus is to investigate the ISCX towards the preventive measures in fulfilling the customers' physiological and basic needs through the utilisation of this framework. This study used a qualitative descriptive approach utilising the thematic analysis to identify its customers' experiences on the retailer's preventive measures during COVID-19 pandemic. These measures were collected and analysed through Atlas.ti software. This study will provide insights for future researches to investigate further on how retailers' preventive measures affect ISCX; as the new coronavirus, COVID-19 is not the first threatening disease that's surged worldwide. It also will provide more suggestions to policymakers and businesses on preventive measures deemed to be suitable for future implementation of the guideline. This research will also support Sustainable Development Goal 3 for Good Health and Well-Being which helps end the COVID-19 pandemic as an infectious disease.
\end{abstract}

Keywords: Preventive Measures, Consumer Experience, COVID-19, Retailers, Malaysia, SDG3

\section{Introduction}

In the early year 2020, the world was shaken with the Coronavirus (COVID-19) outbreak which was later declared by The World Health Organization (WHO) as a pandemic. The virus that was initially started in Wuhan, China spreads very fast as it primarily spreads during close contacts between people. As an infectious person coughs, sneezes or even talks to others, droplets produced can transmit the virus to other people around. A team of Harvard scientists predicted that social distancing might be needed until the year 2022 unless the vaccine is found (AFP, 2020). For the global community as a whole, this is the first encounter where the health crisis has resulted in worldwide socioeconomic disruption in which the consumer behaviours, organisations and supply chains are expected to shift to the "new normal" (McKinsey, 2020). Experts believe that these social distancing rules could significantly shrink the retailers' in-store sales growth (Arcieri, 2020). As retailers are forced to implement new 
protocols that will limit capacity and discourage shoppers from socialising and wandering around, the spending pattern and trend is expected to be different from the pre-pandemic days (Arcieri, 2020).

To remain relevant, retailers that prioritised physical stores and face-to-face engagement has to quickly adapt to the new normal in retail (Briedis, Kronschnabl, Rodriguez, \& Ungerman, 2020). In Malaysia, following the WHO recommendations, among the social distancing guidelines that have been laid out by the country's Ministry of Health (MOH) are for people to maintain at least one-metre distance from each other, wash hand frequently with soap or hand sanitiser and wear the mask in crowded places ( $\mathrm{MOH}, 2020)$. With regards to this study, $60 \%$ of Malaysian shopped online and offline during 2020's Movement Control Order (statisca.com, 2020); specifically with 49\% of them preferring shopping in person (Jaafar, 2020). Even though the shopping preference of Malaysian citizens has changed during this pandemic, there is still a significant number of them who choose to shop in the store. This situation should push the retailers to implement policies and processes that prioritise sanitation and cleanliness.

However, while many feel that social distancing should still be practised even after the movement control order (MCO) has been lifted (Zainal, 2020); it is still unclear how these preventive measures affect the in-store customer experience (ISCX) mainly. ISCX is significant as it influences vital performance variables such as satisfaction and store loyalty (Bustamante $\&$ Rubio, 2017). Previously, social interactions and hedonic values such as joy and leisure are essential in ICSX (Bagdare \& Jain, 2013; Bustamante \& Rubio, 2017). Nevertheless, with the COVID-19 pandemic, automation trend increases and human contact is minimised, if not eliminated (Arcieri, 2020). Customers tend to cut short their time in-store and providing safe customer experiences are the utmost important to ease their anxieties (Briedis et al., 2020). Therefore, in fulfilling the gap, this study aims to explore customer experience towards COVID-19 preventive measures of Malaysian retailers. To do so, this study proposes a conceptual framework of ISCX and preventive measures within the implementation of the Maslow Hierarchy of Needs concept. Eventually, the upcoming focus is to investigate the ISCX towards the preventive measures in fulfilling the customers' physiological and basic needs through the utilisation of this framework.

This study will provide insights for future researches to investigate further on how retailers' preventive measures affect ISCX; as the new coronavirus, COVID-19 is not the first threatening disease that's surged worldwide. It also will provide more suggestions to policymakers and businesses on preventive measures deemed to be suitable for future implementation of the guideline. This study also supports the Sustainable Development Goal 3, Good Health and Well-Being by the United Nations, that helps in ending COVID-19 pandemic as an infectious disease. The purpose of this goal is to ensure healthier lives at all ages and encourage well-being (United Nations, 2018) which is the utmost priority for COVID19 pandemic. By implementing crucial preventive measures in all Malaysian stores, it will help reduce the risk of getting COVID-19 infection (World Health Organisation, 2020).

\section{Customer Experience (CE) During Covid-19 Pandemic}

Previous scholars had debated and theorised customer experience (CE) during the last three decades. Holbrook \& Hirschman (1982) described the experience of consumption as involving various playful leisure activities, sensory pleasures, daydreams, visual pleasure and emotional responses. It was later described as the aggregate and cumulative perception of customers generated during the learning, acquisition, usage, maintenance and disposal of a product or 
service (Carbone \& Haeckel, 1994). Pine \& Gilmore, (1998) defined experiences in a seminal work as "economic offers" which are "inherently personal responses that occur only in the mind of an individual engaged on a mental, physical, intellectual, or even spiritual basis." These concepts were also confirmed by De Keyser, Lemon, Klaus, \& Keiningham, (2015) which define customer experience as "consisting of the cognitive, mental, physical, physiological, moral, and social elements that mark the direct or indirect contact of the customer with (an) other business actors".

Following these definitions, customer experience during COVID-19 pandemic in Malaysia will be reformed due to people's awareness on curbing this virus infection within the community. The threat of contracting COVID-19 leads people to be on high alert to it and take several preventive measures such as wearing a face mask, and social distancing (Casale \& Flett, 2020). Fear, anxiety, and worry among customers are now the new normal and likely to occur (Ahorsu et al., 2020; Pakpour \& Griffiths, 2020). Since there were some related components in the previous CE's concepts such as leisure and other pleasures, the customers might experience differently due to this pandemic; thus this new phenomenon will be reflected in this study's result.

\section{In-Store Customer Experience (ISCX) Dimensions}

This study will be conducted within the retail setting of the customers' experience. To decide on its' measurements, a review of retail's customer experience was done on researches such as Bagdare \& Jain, (2013); Bustamante \& Rubio, (2017); Deshwal, (2016); Hermes \& Riedl, (2020); Ogruk, Anderson, \& Nacass, (2018). There were several theoretical developments on CE's measurements on retail settings previously.

Considering the study's setting will take place among in-store customers, this study has chosen the measurement from Bustamante \& Rubio, (2017) since these researchers provide In-Store Customer Experience (ISCX) among retailers. The measurements also were not biased towards any related situations that might not occur during COVID-19 pandemic. The measurements' descriptions from these researchers were renamed to Code ISCX1 to ISCX4 to facilitate the thematic analysis of this study in the future. The ISCX's codes are as follow:

\section{Cognitive Experience (Code: ISCX1)}

Cognition is gained by experience, learned knowledge and subjective qualities to be perceived by individuals. It is what helps people to identify and address specific issues to the detriment of others (Da Silva \& Syed, 2006; David, Miclea, \& Opre, 2004; Dimofte, 2010). With regards to this study, the cognitive experience will be inquired of the participants on the retailers' overall environment of their stores, including their products' display, services and preventive measures taken during COVID-19 pandemic.

\section{Affective Experience (Code: ISCX2)}

The affective mechanism is conceptualised as a "valenced feeling state," and its structure involves mood and emotion (Cohen \& Areni, 1991; Erevelles, 1998; Richins, 1997). In terms of intensity, affective responses differ, from mildly positive or negative moods to extreme positive or negative feelings (Schmitt, 1999). When researching ISCX, this study would concentrate on the emotion of consumers rather than moods, as emotions are associated with an object that activates them and is more intense, while moods are usually not correlated with an object that stimulates them and is in low of intensity (Erevelles, 1998). 


\section{Social Experience (Code: ISCX3)}

In a social context, the experience is built together with other people. Physical retail outlets are social environments in which the customer perceives, interprets and communicates with the service elements to engage in individual and collective processes (Vargo \& Lusch, 2008). Concerning this study, the participants will be asked on their interactions with other people in retailers' stores, which includes other customers and staff of the retail shop.

\section{Physical Experience (Code: ISCX4)}

ISCX's physical aspect relates to the physiological responses of customers in their interaction with the environment (Bitner, 1992). This response can be defined as a state of well-being/comfort or lack of comfort/discomfort (De Looze, Kuijt-Evers, \& Van Dieën, 2003; Kuijt-Evers, Groenesteijn, De Looze, \& Vink, 2004). Through this aspect, the participants of the study will be required to explain their level of comfort towards the overall environment of the visited retailers' stores, with the inclusion of preventive measures taken by these shops.

\section{Preventive Measures During Covid-19}

Preventive measures among retailers during COVID-19 pandemic is essential to reduce the virus widespread in a country. For Malaysia, the Ministry of Health has urged all businesses to step up the implementation of COVID-19 preventive measures at their respective premises (Bernama, 2020b). Malaysia's Ministry of Domestic Trade and Consumer Affairs has come out with a standard operation procedure (SOP) for certain retailers during the movement control order in the country (KPDNHEP, 2020). However, there are several differences among preventive measures articles during COVID-19 compared to this SOP. This study gathered several other reliable articles together with SOP provided by the Malaysian ministry to come with related substantial preventive measures components.

Concerning this matter, preventive measures during COVID-19 among literature were extracted throughout 31 articles which includes past research, companies' press releases, procedures, and newspapers. These measures were collected and analysed through Atlas.ti software to give overall components of what a retailer should implement on their premises. Several codes were then identified and given the code name from Code PM5 to Code PM11. Table 2 below shows the collected preventive measures codes and quotations defined within each code. 
TABLE 2: Preventive Measures Codes During COVID-19

\begin{tabular}{|c|c|c|}
\hline $\begin{array}{l}\text { Preventive Measure (PM) } \\
\text { Codes }\end{array}$ & $\begin{array}{l}\text { Quotation } \\
\text { Frequency }\end{array}$ & Authors \\
\hline Code PM5: Social Distance & 18 & $\begin{array}{l}\text { Aguero et al., (2011); Basile et al., (2020); } \\
\text { Bernama, (2020a); Dalton et al., (2020); } \\
\text { Harun, (2020); KPDNHEP, (2020); Ming, } \\
\text { (2020); MOH, (2020); Pezzini, (2020); } \\
\text { Phua, (2020); World Health Organization } \\
\text { (WHO), (2019) }\end{array}$ \\
\hline Code PM6: Hand Sanitizers & 16 & $\begin{array}{l}\text { Aguero et al., (2011); Basile et al., (2020); } \\
\text { Bernama, (2020c); Dalton et al., (2020); } \\
\text { Digi, (2020); Ming, (2020); Narain, Kumar, } \\
\text { \& Bhatia, (2009); Pezzini, (2020); Shell } \\
\text { Malaysia, (2020); Phua, (2020); Torre et } \\
\text { al., (2009); World Health Organization } \\
\text { (WHO), (2019); KPDNHEP, (2020) }\end{array}$ \\
\hline Code PM7: Face Mask & 16 & $\begin{array}{l}\text { Aguero et al., (2011); Balkhy et al., (2010); } \\
\text { Basile et al., (2020); Bernama, (2020b); } \\
\text { Bults et al., (2011); Digi, (2020); Harun, } \\
\text { (2020); KPDNHEP, (2020); Ming, (2020); } \\
\text { Bernama, (2020a); TheStraitsTimes, } \\
\text { (2020); Zolkepli, (2020) }\end{array}$ \\
\hline $\begin{array}{l}\text { Code PM8: On-Premise } \\
\text { Sanitation }\end{array}$ & 14 & $\begin{array}{l}\text { Aguero, Adell, Perez Gimenez, Lopez } \\
\text { Medina, \& Garcia Continente, (2011); } \\
\text { Bernama, (2020a, 2020b, 2020c); CDC, } \\
\text { (2020); Dalton, Corbett, \& Katelaris, } \\
\text { (2020); Digi, (2020); Hanafiah, Azman, } \\
\text { Jamaluddin, \& Aminuddin, (2016); Harun, } \\
\text { (2020); KPDNHEP, (2020); Pezzini, (2020); } \\
\text { Sadique et al., (2007); Shell Malaysia, } \\
\text { 2020) }\end{array}$ \\
\hline $\begin{array}{l}\text { Code PM9: Temperature } \\
\text { Detection }\end{array}$ & 8 & $\begin{array}{l}\text { Basile et al., (2020); Bernama, (2020b); } \\
\text { Canon, (2020); Digi, (2020); Ming, (2020); } \\
\text { Shell Malaysia, (2020) }\end{array}$ \\
\hline $\begin{array}{l}\text { Code PM10: Effective Store } \\
\text { Payment Checkout }\end{array}$ & 2 & Phua, (2020) \\
\hline Code PM11: Store Airflow & 2 & Dalton et al., (2020); Lee et al., (2008) \\
\hline
\end{tabular}

With regard to this study, only Code PM5 to PM8 is considered the most essential preventive measure components since their code frequency was more than ten (10) and mentioned by the formal procedure provided by Malaysia's Ministry of Domestic Trade and Consumer Affairs (KPDNHEP, 2020). According to this procedure, Social Distance (Code PM5) required all individuals in the store area to remain within 1 metre, and it is compulsory for the retailers to mark the gap on the floor, desk and chairs. Furthermore, Hand Sanitizer (Code PM6) are required to be placed by these retailers on the front door or related places in their stores. Moreover, wearing Face Mask (Code PM7) currently is compulsory to follow; thus, the retailers must provide it to their employees. On the other hand, retailers must carry out On- 
Premises Sanitation (Code PM8) process before each of their shifts or operations following the guidelines set by the Ministry of Health Malaysia.

The participants will be asked on their overall shopping experience during COVID-19 pandemic and their perception towards the implementation of retailers' preventive measures. Even though Code PM9 to PM11 is not considered as the most essential preventive measures, they might still be taken into consideration if the participants in this study frequently mentioned them within their interviews.

\section{Conceptual Framework: Customer Experience and Covid-19 Preventive Measures in The Maslow Hierarchy of Needs}

Maslow Hierarchy of Needs was introduced by Abraham Maslow (Maslow, 1962), and his concept was based on psychological needs (self-esteem, love, self-actualisation) and other basic needs (physiological and safety). According to the author, the psychological needs will only become significant after the basic needs have been fulfilled. During COVID-19 pandemic, Malaysian are focusing on buying more necessity items such as raw materials for cooking, household cleaners, and personal care items (Kong, 2020) that fulfil their physiological and safety needs. According to a survey from Ipsos Malaysia, $65 \%$ of Malaysians will stock up their food, and $53 \%$ of them will keep the food for at least one week through weekly grocery shopping. There is also an increase of $27 \%$ of total expenditures on food and non-alcoholic beverages, while other spending such as clothing and footwear, furnishings and recreation are shown a significant decrease of expenses during this pandemic (Kong, 2020).

Due to this change of consumer buying behaviour, Maslow's theory of human needs fits well in the context of COVID-19 as the basic needs are hierarchically arranged and supersedes the others when ones are satisfied. The basic physiological needs are the lowest and fundamental for the survival of individuals. In this case, these needs seem to be overlapping with safety and security needs. Such needs usually emerge from deprivation and the absence of which develops a sense of anxiety and stress. It can be attributed to the idea that people may think an empty stomach (without food, water, and other routine essentials during lockdown) would take their life away before the coronavirus (Singh, 2020).

Concerning this study, it will emphasise the basic human needs within Maslow's theory that consists of physiological and safety needs. The consumer's buying experience in the retailers' store (ISCX) on fulfilling their physiological needs will be placed on the lowest fundamental of Maslow's model, while their experience facing retailers' preventive measures as the means to ensure their safety will be in safety needs. Figure 1 illustrated the study's conceptual model to enlighten the organisation of ideas within the Maslow Hierarchy of Needs theory. 
FIGURE 1: Conceptual Framework: In-Store Consumer Experience (ISCX) and Retailer's Preventive Measure in Maslow Hierarchy of Needs

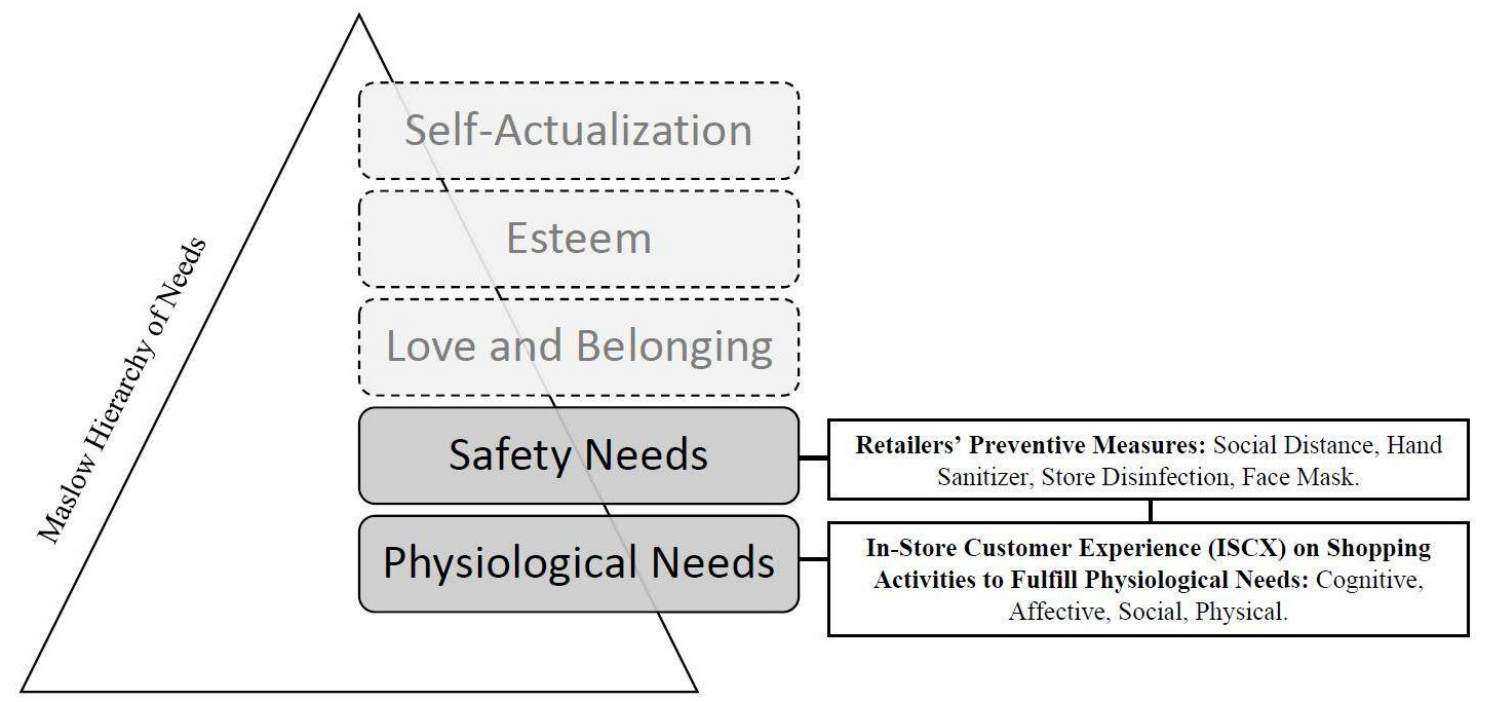

Adapted from: Bustamante \& Rubio, (2017) and Maslow, (1962)

\section{Methods}

\section{Research Design}

This study used a qualitative descriptive approach utilising the thematic analysis to identify its customers' experiences on the retailer's preventive measures during COVID-19 pandemic. The qualitative descriptive approach fits within the constructivist paradigm in which learning takes place between the interviewer and the participants (Lincoln \& Guba, 2005). Data gathered from qualitative descriptive research underlines the importance of presenting information as it exists in readily understood terms. For the priority placed on learning between interviewer and participant, a qualitative descriptive methodology was selected. In this study, the interviewers are Malaysian researchers and academicians, while all participants were Malaysian customers which creates a right balance and comprehensible qualitative data.

Throughout the use of Atlas.ti software on this study's literature, a qualitative approach will support its research process by identifying the same theme between; 1 ) the initial ISCX and PM codes found among previous articles, and 2) the participants' feedback in the data analysis phase. By comparing these initial codes to the participants' feedback, new findings might emerge and will be given codes as the data analysis of this study takes place. The initial codes from the literature were concluded as follows: 
TABLE 3: A Summary of Initial Codes

\begin{tabular}{lll}
\hline No. & Codes & Study Items \\
\hline 1 & ISCX1 & Cognitive Experience \\
2 & ISCX2 & Affective Experience \\
3 & ISCX3 & Social Experience \\
4 & ISCX4 & Physical Experience \\
5 & PM5 & Social Distancing \\
6 & PM6 & Hand Sanitisers \\
7 & PM7 & Face Mask \\
8 & PM8 & On-Premise Sanitation \\
9 & PM9 & Temperature Detection \\
10 & PM10 & Effective Payment Checkout \\
11 & PM11 & Store Airflow \\
\hline
\end{tabular}

\section{Research Setting}

Malaysia is one of the 213 countries around the world which have been affected by the COVID-19 virus. With more than 60,000 positive cases in November 2020 (worldometers.info, 2020), this country is still struggling to find its way in curbing the spread of the virus. Klang Valley (Kuala Lumpur, Selangor and Putrajaya) holds more than the $50 \%$ of total COVID-19 cases in Malaysia which has become the area containing the largest case numbers in the entire country $(\mathrm{MOH}, 2020)$.

Furthermore, this study will take place on Klang Valley customers who visited retailers for purchasing their everyday items on any Malaysian Movement Control Order period. Standard of Operation (SOP) on preventive measures had been announced by the Malaysian government for these retailers and their customers to follow its rules and regulation.

\section{Sample}

Purposive sampling will be used to gather participants in this study. The sampling was intentional and purposeful to incorporate the feedback of individuals who have potential to engage and enact meaningful meaning of buying experience in retailers' premises during any phases of Movement Control Order (MCO) on COVID-19 pandemic. The researchers will find and contacted ten (10) participants who fulfil the study's criteria which are as follows:

1. The participant must be a Malaysian citizen; and

2. The participant is a customer of any retailers in Klang Valley, Malaysia; and

3. The participant must have the buying experience at any retailers in Klang Valley, Malaysia during any phases of Malaysia's Movement Control Order (MCO); and

4. The participant must purchase any items within the retailers' premises without pick up or online delivery methods; and

5. The participant can recall their experience purchasing any items inside the retailers' premise with their involvement in preventive measures applied by the store.

\section{Interviews}

Since the COVID-19 hits Malaysia in early 2020, the social distancing in several economic sectors has been applied as one of the preventive measures during this pandemic. Due to this restriction, the face to face interview with the participants in this study will take place through online video conferencing through Google Meet, an app used for real-time meetings on the World Wide Web. During this online conversation, the interview will be recorded through this 
app with the permission of the participants; thus they will be given a consent form on the platform that includes information regarding the purpose of the study, their ability to withdraw at any point, and the right to video record interviews. They will be allowed to ask questions and were enrolled in the study upon agreeing to participate with verbal consent. The meetings are estimated to last sixty minutes for one participant.

Furthermore, the semi-structured interviews were composed of 10 open-ended statements that allowed the participant to share their knowledge on this study's topic. The initial questions (Can you describe preventive measures taken by the retailers that you frequently shop for?) will be focused on the awareness of any preventive measures utilised by the Malaysian retailers they visited during MCO. Questions will then be directed towards their experience and emotions (How do you feel about the preventive measures undertaken by the retailers during the Covid-19?) on the implementation of these measures. Upon hearing the participant's response to the leading prompt, the interviewer will then ask clarifying questions. The interviews will be conducted in English or Bahasa Malaysia, the national language of Malaysia.

\section{Conclusion}

In essence, this study develops a framework on customer experience towards COVID19 preventive measures of Malaysian retailers. Preventive measures among retailers during the COVID-19 pandemic is essential to reduce the virus widespread in a country. The study will be conducted within the retail setting of the customers' experience. Concerning the pandemic outbreak, it will emphasise the basic human needs within Maslow's theory that consist of physiological and safety needs. The consumer's buying experience in the retailers' store (ISCX) on fulfilling their physiological needs will be placed on the lowest fundamental of Maslow's model, while their experience facing retailers' preventive measures as the means to ensure their safety will be in safety needs.

Specifically, this study proposes a conceptual framework of ISCX and preventive measures within the implementation of the Maslow Hierarchy of Needs concept. Eventually, the upcoming focus is to investigate the ISCX towards the preventive measures in fulfilling the customers' physiological and basic needs through the utilisation of this framework. Thus, this study will provide insights for future researches to investigate further on how retailers' preventive measures affect ISCX; as the new coronavirus, COVID-19 is not the first threatening disease that's surged worldwide. This study can also be used by various government agencies (e.g., Ministry of Health, Ministry of Domestic Trade and Consumer Affairs) and retailers (Tesco, Aeon Mall, Mydin Mall) as a guideline in assessing preventive measures of retail in Malaysia. It will also provide more suggestions to policymakers and businesses on preventive measures deemed suitable for future implementation of the guideline.

\section{References}

AFP. (2020). Social distancing may be needed until 2022. Nst.Com.My. Retrieved from https://www.nst.com.my/world/world/2020/04/584379/social-distancing-may-beneeded-until- 2022

Aguero, F., Adell, M. N., Perez Gimenez, A., Lopez Medina, M. J., \& Continente, G. X. (2011). Adoption of preventive measures during and after the 2009 influenza A (H1N1) virus pandemic peak in Spain. Preventive Medicine, 53(3), 203-206. https://doi.org/10.1016/j.ypmed.2011.06.018

Ahorsu, D. K., Lin, C. Y., Imani, V., Saffari, M., Griffiths, M. D., \& Pakpour, A. H. (2020). The fear 
of COVID-19 scale: Development and initial validation. International Journal of Mental Health and Addiction, 1-9.

Arcieri, K. (2020). Social distancing rules could temper retailers ' in-store sales growth experts. Retrieved from https://www.spglobal.com/marketintelligence/en/newsinsights/latest-news-headlines/social-distancing-rules-could-temper-retailers-in-storesales-growth-8211-experts-57995523

Bagdare, S., \& Jain, R. (2013). Measuring retail customer experience. International Journal of Retail and Distribution Management, 41(10), 790-804. https://doi.org/10.1108/IJRDM08-2012-0084

Balkhy, H. H., Abolfotouh, M. A., Al-hathlool, R. H., \& Al-jumah, M. A. (2010). Awareness, attitudes, and practices related to the swine influenza pandemic among the Saudi public. BMC Infectious Diseases, 10(42), 1-7.

Basile, C., Combe, C., Pizzarelli, F., Covic, A., Davenport, A., Kanbay, M., ... Mitra, S. (2020). Recommendations for the prevention, mitigation and containment of the emerging SARS-CoV-2 (COVID-19) pandemic in haemodialysis centres. Nephrology Dialysis Transplantation, 2, 1-4. https://doi.org/10.1093/ndt/gfaa069

Bernama. (2020a). Govt mulls compulsory use of face masks in public areas - Muhyiddin. Bernama.Com. Retrieved from https://www.bernama.com/en/general/news_covid19. php?id=1862382

Bernama. (2020b). Khalid : KL mall operators urged to increase Covid-19 preventive measures. MalayMail.Com. https://www.malaymail.com/news/malaysia/2020/02/15/khalid-kl-mall-operatorsurged-to-increase-covid-19-preventive-measures/1837862

Bernama. (2020c, March 13). Malls, offices step up preventive measures against COVID-19. Bernama. Retrieved from https://www.theedgemarkets.com/article/malls-offices-steppreventive-measures-against-covid19

Bernama. (2020d). Hair salons must take preventive measures against Covid-19. Bernama. Retrieved from https://www.nst.com.my/news/nation/2020/04/583351/hair-salonsmust-take-preventive- measures-against-covid-19

Bitner, M. J. (1992). Servicescapes: the impact of physical surroundings on customers and employees. Journal of Marketing, 56(2), 57-71. https://doi.org/10.20595/jjbf.19.0_3

Briedis, H., Kronschnabl, A., Rodriguez, A., \& Ungerman, K. (2020). Adapting to the next normal in retail: The customer experience imperative. Retrieved from https://www.mckinsey.com/industries/retail/our-insights/adapting-to-the-nextnormal-in-retail-the-customer-experience-imperative

Bults, M., Beaujean, D. J. M. A., De Zwart, O., Kok, G., Van Empelen, P., Van Steenbergen, J. E., ... Voeten, H. A. C. M. (2011). Perceived risk, anxiety, and behavioural responses of the general public during the early phase of the Influenza $A(H 1 N 1)$ pandemic in the Netherlands: Results of three consecutive online surveys. BMC Public Health, 11, 1-13. https://doi.org/10.1186/1471-2458-11-2

Bustamante, J. C., \& Rubio, N. (2017). Measuring customer experience in physical retail environments. Journal of Service Management, 28(5), 884-913. https://doi.org/10.1108/JOSM-06-2016-0142

Canon. (2020). Canon COVID-19 preventive measures. Retrieved from Canon website: https://my.canon/en/consumer/web/covid-19-precautionary-measures

Carbone, L. P., \& Haeckel, S. H. (1994). Engineering customer experience. Marketing Management, 3(3), 8-19. 
Casale, S., \& Flett, G. L. (2020). The COVID-19 pandemic as an objective and psychological situation. Clinical Neuropsychiatry, 17(2), 88-93.

Cohen, J. B., \& Areni, C. S. (1991). Affect and consumer behavior. In H. H. (Eds) Robertson, T. S. and Kassarjian (Ed.), Handbook of Consumer Behavior (pp. 188-240). Englewood Cliffs, NJ: Prentice-Hall.

Da Silva, R. V., \& Syed, S. F. (2006). Cognitive, affective attributes and conative, behavioral responses in retail corporate branding. Journal of Product and Brand Management, 15(5), 293-305.

Dalton, C., Corbett, S., \& Katelaris, A. (2020). Pre-emptive low-cost social distancing and enhanced hygiene implemented before local COVID-19 transmission could decrease the number and severity of cases. The Medical Journal of Australia, 212(10), 1-10. https://doi.org/10.2139/ssrn.3549276

David, D., Miclea, M., \& Opre, A. (2004). The information-processing approach to the human mind: Basics and beyond. Journal of Clinical Psychology, 60(4), 1-3.

De Keyser, A., Lemon, K. N., Klaus, P., \& Keiningham, T. L. (2015). A framework for understanding and managing the customer experience. Cambridge, MA.

De Looze, M. P., Kuijt-Evers, L. F., \& Van Dieën, J. (2003). Setting comfort and discomfort and the relationships with objective measures. Ergonomics, 46(10), 985-997. https://doi.org/10.16309/j.cnki.issn.1007-1776.2003.03.004

Deshwal, P. (2016). Customer experience quality and demographic variables (age, gender, education level, and family income) in retail stores. International Journal of Retail and Distribution Management, 44(9), 940-955. https://doi.org/10.1108/IJRDM-03-20160031

Digi. (2020). Digi steps up precautionary measures in light of Covid-19 to protect customers and employees. Retrieved from Digi website: https://www.digi.com.my/aboutus/media/press-releases/en/digi-steps-precautionary-measures-light-covid-19-protectcustomers

Dimofte, C. V. (2010). Implicit measures of consumer cognition: a review. Psychology \& Marketing, 27(10), 921-937.

Erevelles, S. (1998). The role of affect in marketing. Journal of Business Research, 42(3), 199215.

Hanafiah, M. H., Azman, I., Jamaluddin, M. R., \& Aminuddin, N. (2016). Responsible tourism practices and quality of life: Perspective of Langkawi island communities. Procedia Social and Behavioral Sciences, 222, 406-413. https://doi.org/10.1016/j.sbspro.2016.05.194

Harun, H. N. (2020). Shopping malls urged to implement preventive measures for Covid-19. Retrieved from New Straits Times website: https://www.nst.com.my/news/nation/2020/02/565484/shopping-malls-urgedimplement-preventive-measures-covid-19

Hermes, A., \& Riedl, R. (2020). The nature of customer experience and its determinants in the retail context: Literature review. International Business Informatics Congress, (March), 1738-1749. https://doi.org/10.30844/wi_2020_r5-hermes

Holbrook, M. B., \& Hirschman, E. C. (1982). The experiential aspects of consumption: Consumer fantasies, feelings, and fun. Journal of Consumer Research, 9(2), 132-140.

Jaafar, S. S. (2020). Over two-thirds of Malaysians now more comfortable shopping online after Covid-19 - StanChart. Theedgemarkets.Com. Retrieved from https://www.theedgemarkets.com/article/over-twothirds-malaysians-now-more- 
comfortable-shopping-online-after-covid19---stanchart

Kong, S. (2020). Covid-19 changes consumer buying behaviours. Borneo Post Online. Retrieved from https://www.theborneopost.com/2020/04/26/covid-19-changesconsumer-buying-behaviours/

KPDNHEP. (2020). Prosedur Operasi Standard Serta Pergerakan Pekerja Bagi Elektrik \& Elektronik. Retrieved from

https://www.miti.gov.my/miti/resources/Prosedur_Operasi_Standard_Am_dan_Garis_ Panduan_Kebenaran_Beroperasi_serta_Pergerakan_Pekerja_bagi_Syarikat_@_Premis _Dobi,_Hardware,_Elektrik_dan_Elektronik_dalam_Tempoh_Perintah_Kawalan_Perger akan.pdf

Kuijt-Evers, L. F., Groenesteijn, L., De Looze, M., \& Vink, P. (2004). Identifying factors of comfort in using hand tools. Applied Ergonomics, 35(5), 435-458.

Lee, V. J., Wong, C. S., Tambyah, P. A., Cutter, J., Chen, M. I., \& Goh, K. T. (2008). Twentieth century influenza pandemics in Singapore. Annals of the Academy of Medicine Singapore, 37(6), 470-476.

Lincoln, Y. S., \& Guba, E. G. (2005). Paradigmatic controversies, contradictions and emerging confluences. In The Sage Handbook of Qualitative Research (pp. 191-215). California: Sage Publishing, Inc.

Maslow, A. H. (1962). Toward a psychology of being. Princeton (D. Van Nostrand Company).

McKinsey. (2020). COVID-19: Briefing materials. Retrieved from https://www.mckinsey.com/business-functions/risk/our-insights/covid-19implications-for-business

Ming, F. (2020). Preventive measures while in grocery stores during COVID-19 pandemic By Professor Dr Moy Foong Ming. Sinchew.Com.My. Retrieved from https://www.sinchew.com.my/content/content_2251305.html 2020-04-11

MOH. (2020). Covid-19 : Social Distancing Guidelines for Workplace, Homes and Individuals. Retrieved from https://www.moh.gov.my/moh/resources/Penerbitan/Garis Panduan/COVID19/Annex_26_COVID_guide_for_Social_Distancing_24032020.pdf

Narain, J. A. I. P., Kumar, R., \& Bhatia, R. (2009). Pandemic (H1N1) 2009: Epidemiological, clinical and prevention aspects. The National Medical Journal of India, 22(5), 1-6.

Ogruk, G., Anderson, T. D., \& Nacass, A. S. (2018). In-store customer experience and customer emotional state in the retail industry. Journal of Research for Consumer, (32), 110-141. https://doi.org/10.1017/CBO9781107415324.004

Pakpour, A. H., \& Griffiths, M. D. (2020). The fear of COVID-19 and its role in preventive behaviors. Journal of Concurrent Disorders.

Pezzini, G. (2020). How to keep your retail employees and customers safe during the COVID19 pandemic. 1sretail.Com, p. 2020. Retrieved from

https://www.Isretail.com/blog/keep-retail-employees-customers-safe-during-covid-19pandemic

Phua, R. (2020). Measures for safe distancing rolled out at retail, F\&B sectors to prevent COVID-19 spread. Channelnewsasia.Com. Retrieved from

https://www.channelnewsasia.com/news/singapore/covid19-safe-distancingrecommendations-retail-restaurants-12560568

Pine, B. J., \& Gilmore, J. (1998). Welcome to the experience economy. Harvard Business Review, 78(1), 97-105.

Richins, M. L. (1997). Measuring emotions in the consumption experience. Journal of Consumer Research, 24(2), 127-146. 
Sadique, M. Z., Edmunds, W. J., Smith, R. D., Meerding, W. J., De Zwart, O., Brug, J., \& Beutels, P. (2007). Precautionary behavior in response to perceived threat of pandemic influenza. Emerging Infectious Diseases, 13(9), 1307-1313. https://doi.org/10.3201/eid1309.070372

Shell Malaysia. (2020). Preventive measures for your safety. Retrieved from Shell website: https://www.shell.com.my/motorists/inside-our-stations/covid19.html

Singh, P. (2020). Abraham Maslow's 'Hierarchy of Needs' becomes even more relevant in the era of COVID-19. Retrieved from psychreg.org website:

https://www.psychreg.org/hierarchy-of-needs-covid-19/

Statisca.com. (2020). Consumers who shopped on both online and offline channels from phase 1 to phase 3 of the Movement Control Order (MCO) period during the COVID-19 pandemic in Malaysia in 2020. Retrieved from statisca.com website: https://www.statista.com/statistics/1119120/malaysia-offline-and-online-shoppingcovid-19-mco/

TheStraitsTimes. (2020). Malaysia implements mandatory mask-wearing in crowded places from Aug 1. Straitstimes.Com. Retrieved from https://www.straitstimes.com/asia/seasia/malaysia-implements-mandatory-mask-wearing-in-crowded-places-from-aug-1

Torre, G. La, Thiene, D. Di, Cadeddu, C., Ricciardi, W., \& Boccia, A. (2009). Behaviours regarding preventive measures against H1N1 influenza among Italian healthcare workers. Eurosurveillance, 14(49), 19432.

UnitedNations. (2018). 3 Good health and well-being. https://doi.org/10.1891/9780826190123.0014

Vargo, S. L., \& Lusch, R. F. (2008). Service-dominant logic: continuing the evolution. Journal of the Academy of Marketing Science, 36(1), 1-10.

World Health Organisation. (2020). COVID-19 transmission and protective measures. Retrieved from who.int website:

https://www.who.int/westernpacific/emergencies/covid-19/information/transmissionprotective-measures

World Health Organization (WHO). (2019). Basic protective measures against the new coronavirus. Retrieved from World Health Organization website: https://www.who.int/emergencies/diseases/novel-coronavirus-2019/advice-for-public

Zainal, N. H. (2020). Social distancing preferred. Thestar.Com.My. Retrieved from https://www.thestar.com.my/news/nation/2020/04/29/social-distancing-preferred Social

Zolkepli, F. (2020). Face mask compulsory from Aug 1. Thestar.Com.My. Retrieved from https://www.thestar.com.my/news/nation/2020/07/24/face-mask-compulsory-fromaug-1 